\title{
The Justification of 2002 Ethiopian Foreign and National Security Policy Alteration
}

\author{
Xi Chen, Yeheys Nardos Hawaz \\ School of International and Public Affairs of Jilin University, Changchun, China \\ Email: freyafloat@163.com, yeheys9918@mails.jlu.edu.cn
}

How to cite this paper: Chen, X., \& Hawaz, Y. N. (2020). The Justification of 2002 Ethiopian Foreign and National Security Policy Alteration. Open Journal of Social Sciences, 8, 12-25.

https://doi.org/10.4236/jss.2020.87002

Received: May 26, 2020

Accepted: July 4, 2020

Published: July 7, 2020

Copyright $\odot 2020$ by author(s) and Scientific Research Publishing Inc. This work is licensed under the Creative Commons Attribution International License (CC BY 4.0).

http://creativecommons.org/licenses/by/4.0/

(c) (i) Open Access

\begin{abstract}
This article examines how the 2002 Ethiopia's foreign policy has failed to keep up with current issues and examines the reasons for the change. The policy has not been revised for many years, and no efforts have been made to integrate it into a number of local political reform, neighboring countries, and international issues. It is designed in a way protect the national interest and sets out a safety precaution, detailing issues that could hurt Ethiopia. As a result, it is largely a matter of fact that it has not been developed in a way dealing the statuesque. Now, the government has made improvements to the country's political institutions and government structure. Ethiopia's political achievement is highly acknowledged internationally after Prime Minster Abiy. These changes include governance and administrative changes as listed above. Moreover, there have been some improvements in foreign relations. Thus, this paper explores why the 2002 policy is incompatible with the current foreign relation interest. It explores in detail the why of policy changes Ethiopia may have in the current context. In general, it sees the sights at the wide range of rationale that urges the change of the policy.
\end{abstract}

\section{Keywords}

Foreign Policy, State, Economic Development, National Interest, Political Actor

\section{Introduction}

Foreign policy is the path of state's external relation. All sort of relation shall encompass and fit the policy guideline which defined state's interest. It guides how state reacts with other state in establishing and strengthening relation in broad spectrum. It governs the way the state acts on economic and public diplomacy. 
The essential of foreign policy is undeniably crucial to sovereign state. As to protecting States Sovereignty, the policy is the reflection of State's status quo as well as the world order. In maintain the status quo, culture, economic negotiation, peace keeping, and intelligence are the basic elements of foreign policy between international actors (Alden \& Ara, 2017). However, the policy might be modified or totally changed depend on State's drive.

Ethiopia's foreign policy was adopted in 2002. This policy combines two issues. These are foreign affairs and national security. Therefore, it has policy theories regarding foreign affairs. However, the social, political and economic issues that may arise during the relationship are restricted by certain strategic frameworks to safeguard national security.

The current foreign relation process of Ethiopia is not in accordance with 2002 foreign policy. The government has disclosed new practices and foreign relations interests. The policy of 2002 is nothing more than a single volume document compared to the current political situation in Ethiopia. In general, foreign relations have tended to deviate from the policy direction. In this case, the situation indicated that either the policy or the relation needs to be fixed. From this, it is clear from the government's view that Ethiopia should not go ahead with its foreign relations according to 2002 policy. As a result, it was believed that Ethiopia needed a policy which is relevant to her new political situation and statuesque.

Against this backdrop, the paper will examine why the Ethiopia's 2002 foreign policy did not cop with current political status quo. Accordingly, it is worth examining in detail rational which urges this policy changes.

State's policy focus might change for various reasons. Ethiopia is currently drafting new foreign policy. Why is the previous policy not relevant to the existing situation? What does Ethiopia's political reform have to do with foreign relation? How does the political reform influence the change of the policy? In general, what is the rationale behind this state's motive?

The details of these questions find the reasons for changing the foreign policy of 2002. In order to answer this question, current situation of Ethiopia politics will be investigated. Most causes revolve around the role of political actors. Actor have influence on politics, as this influence grows, it shows the political direction of the country. As a result, policy issue does not go beyond this effect. The study uses Rational choice theory to investigate and foresee the role of actors in the foreign policy statues. The analysis is made based on the supplementary document and narrative from secondary data.

\section{Highlight on the Pillars of 2002 Ethiopia's Foreign Policy}

As policy will issue several changes in states preferences and direction with its external relation, it has also initial bases it stands on. The 2002 Ethiopian foreign policy was combined with national security issues. It describes unless the national security is enhanced, peace and order are unstable. Thus, the urge of for- 
eign relation would be meaningless. The aim is to relay to maximize the economic benefit from foreign relation than security. As long as the security problem occurred nationally it will be the supreme work of national government. It does not let and give any opportunity for foreign intervention in national issues.

The overall theme of Ethiopia's foreign and national security policy was the protection of national economy from liberal thought. Though Ethiopia adopt free market economy, it still closed its door for economic liberaltarian. Thus, the foreign policy was carefully designed with prioritized basis purposefully.

According to the foreign and national policy issued at 2002, the aim, goal and the strategy of Ethiopia's foreign policy was clearly stated. More importantly, the bases of the policy were undoubtedly mentioned. The national issues were taking greater concern from all. The most crucial bases were Security of the state, Development and democracy, National pride and Globalization.

Section one of the policy started with description of these bases. Security was the main concern of the state. The sate shall stabilize peace and security. According this part, other issues should be raised after national security. The development in different sector will be guaranteed if only when security of the state stable.

As democracy is very young in Ethiopia, it needs a greater concern to demonstrate for the public. Development and democracy were inseparable bases of the policy in Ethiopia. Public participation is crucial to overcome the great enemies of Ethiopia which is poverty. These national enemies were stated in detail as Unemployment, illiteracy and poverty. As Security was prioritized as the initial bases, no enemies are considered to tempted the national development. By way of the foreign policy, "poverty and backwardness" were frequently mentioned as the great enemies of Ethiopia.

Development is the tool of overcoming these enemies. Democracy is the platform of it. In order to enhance this development on the democratic plat forms the government urges public engagement in different national conciseness. The areas of developments should be settled, the priority should be sated, the democratic value of the constitution shall late the public to participate on such areas.

The other important bases were national pride and globalization. As Ethiopia had never been colonized, the nation had developed national pride and do not tolerate any external power to humiliate Ethiopia. The foreign policy urges, this generation has also responsibility to perform its duty to develop the country. However, it also stress being nationally pride is not mean isolationist. Ethiopia likes to develop parallel to what is going on externally.

It stresses the world economy is intersected by globalization. Thus, Ethiopia's development cannot be out of it. Being part of globalization or not, was being building either independent or dependent economy in the future. Thus, in order to build strong independent national economy Ethiopia urges the age of globalization as one part of its foreign engagement. Globalization is here used as tools to build productive economy. However, the policy also believes, the fruit of globalization highly depended on give and take system. Thus, poor countries like 
Ethiopia would have a probability to lose a lot than benefiting. Consequently, it stresses on priority to national pride and public service.

As described earlier, the urges were in all to save the economy. As the need of globalization is only to facilitate the economy, the state securitized national companies from the liberal development model. The government had thought these companies had guaranteed the development since long. Thus, liberalizing these economic sectors is passing public interest to the individual interest.

\section{Foreign Policy Changes}

There are numerous literatures on the nature of foreign policy change. The reasons these studies describe the changes in empirical and theoretical manner with regard with statuesque. All countries may need different policy changes at different times, as well as policy changes in relation to external variables, if a sovereign country thinks that external changes will affect the state (Skidmore, 1994). However, most countries are in the process of adjusting themselves to the social changes of the world (Lkenberry, 1986).

However, policy can be modified or changed, there is a big difference between the two. Policy modification is an improvement on specific issues. Changing policy, however, means re-designing or reconstructing. This is a sign that the country has changed its way of seeing the outside world (Holsti, 2016). Policy development largely depends on one leader's thinking. In interactions with the leader before the end of his term of office, the leader may realize that the policy direction needs to be improved. Policy change, however, is widely observed as leaders change. When leaders change, the way they act could be new. Indeed, it is thought that they have won a democratic election with the best and competitive ideas ever. In their new thinking, they may criticize the old regime and prioritize things that need to be improved. Their administration may be interested in close friendship with countries that the former administration claimed as the hostile countries. In such cases, policy cannot be improved. Thus, following such kinds of radical thinking, policy improvement would not help, what is needed is change.

There are also studies that show that domestic policy factors have an impact on policy change. In fact, internal political instability, slowing economic growth, and the level of social cohesion have a profound effect. Dynamic political behavior disrupts actors' decision-making processes. This issue not only weakens actors but also weakens institutions (Rosati, 1994). In such a situation, the relationship with the outside can no longer be healthy. This is a sign of the impact that internal problems have on a relationship.

This is not to say that external factors have no bearing on policy change. The dynamics of world politics may force a country to reconsider its foreign policy. The current state of friendship and hostility also has its effects. The country's policy may change following the increasing and slowing the political, economic and social interaction of neighboring countries. 
Economic ties are not only beneficial to one country but can also lead to negative consequences. If left unchecked, these drops can be dangerous. As has been seen internationally, the affected country is slowly experiencing political unrest. The political instability is due to widespread closure of the economy (Kassab, 2017). Actors often find it difficult to fix these problems. The reason is not that they should adjust their mechanisms to control unrest, but because they need to adjust their regulation and policies. In short, external influences provide a wide variety of contexts for policy change.

The other way of thinking foreign policy change is the claim which describe that foreign policy is largely rigid. As a result, it does not appear to be flexible in different situations or in the context of global conditions. If they do not change this situation in time, they will have problems locally.

\section{The Rational Choice Model}

Rational theory emerges from the initial concept that it is based on the needs of individuals and then of social integration (de Jong, 2012). However, individually or socially, this concept relies on three basic principles. These are decision-making, game rules and behavior patterns (Harsanyi, 1986). Decision-making is very basic. Game law also shows ways to maximize benefits and minimize harm. Behavior explores rationality.

In Rational choice model, the Realist view consider state as Unitary actor. Thus, they taught Foreign policy is key to achieving the government's plans and national goals. It can also provide careful analysis and take early warning in the event of emergencies, hazards and changing events (Mingst \& Arreguintoft, 2011). However, the role of individual actors in this case is not forgotten.

However, there is an issue to be cautious with regard to Rational model theory. This is in keeping Actors with the national interest of the state. Actors can have a high level of commitment in the process of policy formulation and implementation. This does not mean that the interests of actors can replace national interests. Actors are part of the National Interest Initiative. They have the ability to influence and use intermediary skills to accelerate the time that a nation can achieve its national interests (de Mesquita, 2010). They will be at the forefront of the national level and will drive the progress towards change. One thing to keep in mind is that this is a focus on the efficiency of actors. Because of individual differences, every actor has no equal flexibility. Therefore, depending on the behavior of the component, the function of the rational model varies.

The theory widely expressed in two ways. One focuses on the individual and the second focuses on social events. It focuses on the individualism at pre social level, individual history, prioritization, and rigidity characters that emphases on the individual. On the contrary, the opposite works on social events. Thus, the role that rational theory has played is obverting of rational individuals in the chaotic world (Lichbach, 2003). Thus, as there is an individual who is influenced by the culture of the community, there will always be an individual who will in- 
fluence the community through the positive thinking that is generated by the maturity and consciousness. This leads to a higher level of self-awareness when guided by one's own consciousness. Leaders like this were created largely. They use big consciousness in the politics of their country. They use easier options to protect the security and welfare of their nation. They have also helped to make their policy direction better in domestic and their relationship with the foreign countries.

Rational Choice model analyzes an actor's alternatives. The obvious role of the theory can be understood when the actor believes that he/she brings important issues to the organization or accelerates the transformational path and ensures its implementation. Generally, it is believed that the actor's faith also makes social change when actors try to implement an option that he/she believes (Sato, 2013). In fact, organizational, bureaucratic and group psychological approaches are important alongside Rational Choice theories in shaping policy issues. However, the role of the rational theorem is as significant as the role of these three theories.

The role of actors and their influence in practice is reflected the rational choice. Actors are often used to influence political issues to balance their country's political status. This was/is noticeable in the political dynamics of Ethiopia. Their thinking and attitude have been reflected not only in the national, but also in foreign affairs.

The Rational model proves the influence of political actors on foreign policy. In general, actors play a major role in policy-making. From this point of view, its suitable to illustrate how actors influence the policy in Ethiopian context. For that matter, looking at the political situation during 2002 and the current domestic political process is essential. Besides that, actors' views during the 2002 and recent will be contrasted.

For instance, P.M. Melez Zenawi was in power during the ratification of the 2002 policy. Meles and his leading party follows a program called "Revolutionary Democracy" and his government was called "democratic developmental state." (Müller, 2015). At the national and personal levels, Melse strongly condemned the progressive neo-liberal ladder (De Wall, 2012). Meanwhile, he was also doubtful about the Eritrean government's position after the war. In addition, the Horn of Africa is also a conflict zone and had fears that any attack of terrorists from the region.

Personally, if the political actor had such views, it would be clear that they had a major impact on the policy. This is also the catalyst for the role of actors as describing the rational model theory. Accordingly, these were formulated in the policy as the top and priority.

In similar wise, P.M. Abiy has heard frequently speaking about economic reform and liberalization. He also spoke that there is no threat to Ethiopia through Eritrea. In addition, he further discussed the importance of a social and economic integration in East Africa (The Offical Blog of MFA Ethiopia, 2019). 
The new foreign policy addresses these issues. The fact is that, policy is a matter of design following the current political process and cannot be a deviation from default politics. This is not to say that politicians shape policy in their own way. But they do have an impact. Consequently, it is still a policy that has already been influenced by actors.

Ethiopia has regained its influencial leader after the Meles Zenawi, despite their huge personal differences. The prime minister, for example, was cited for his efforts to reach an agreement with the Eritrean government to take the Nobel prize (MLA Style, 2020). In fact, there is evidence that efforts have been made by the previous government. However, it is Dr. Abiy's government that is successful. In other words, the success of this private effort is accompanied by the sudden change in policy described above.

\section{The Architype Factors of the Policy Alteration}

Following the resignation of Prime Minister Hailemariam, Ethiopia reconsider the importance of updating the foreign policy under the new prime minster Abiy Ahmed. This policy line follows the agreement with the Eritrean government, forcing the country to adjust its foreign policy towards Eritrea. On the other hand, the Ministry needs to adjust its outlook on the West in terms of the liberalizing its economy, which is driven by persuasive initiative of Rational choice.

No reform has been made since 2002, when the current foreign policy was adopted. In fact, in Ethiopia, there are no reforms, including the Constitution, and critical policies apart from proclamation issued by the upper house. However, according to the Rational Choice model, the reason for the change in foreign policy can be identified with regard to the rapidly changing world conditions.

However, the outline of the previous policy was problematic, there has been no reform on it for long. Besides the outline, the reason for this change can be seen in two ways. One of these is an immediate cause, which is a reconciliation with the Eritrean government. The Eritrean government may not have faith in the Ethiopian government unless the policy is changed. The Second is the actor's persuasive power domestic politics.

\section{The Immediate Cause for the Urges of the Foreign Policy Alteration}

As to Ethiopia's foreign policy to Eritrea there is no peaceful relationship between the two countries. The Foreign Affairs Policy of 2002 exemplifies the strong inter-ethnic and cultural relationship between the people of Ethiopia and the Eritrea. It also analyzes regional interaction. However, because of the recent bloody wars, it draws the Eritrean government as barbaric. Thus, it stratifies the intense pressure of the relationship indicating the Eritrean government will do a lot to distract Ethiopia (Ministry of Information, 2002).

As a result, the main focus of the policy seems to be on the road to reducing the vulnerability from the policy of the Eretria and Eritrean-led coalition. Al- 
though it is possible to work collaboratively for mutual benefit and growth due to the close relationship between the two countries, it indicates the ruling party was not comfortable with this.

Foreign policy described the Eritrean elite has been as chauvinistic, and anti-democracy. From this, it claims that an outrage of the Ethio-Eritrea war is due to the lack of accountability which emanate from the above seen. While the mild and high goals for the relationship with Eritrea are designed, the policy described that these goals and the relationship will only take place when the authority in power or the policy changes are notified.

In fact, Eritrea considered a major rising power in the region as threat. So, in any way it was a desire to throw a powerful state. However, it was difficult to determine what the goals were at the policy level in Eritrea. Thus, the economic needs or policy implications with other countries were not clear (Healy, 2008).

In general, Ethiopia's foreign policy was firmly committed to strong standpoint against the Eritrean government. It also accused of the Eritrean government sending arms to Ethiopia by organizing, training and supporting armed groups.

Such policy blueprints do not describe countries that have peaceful relations. The leaders of the two countries have now begun peacefully reconciled. As a result, the above policy theories cannot be reflected in the Eritrean government at the moment. Therefore, neither Ethiopia nor Eritrea will have such policies that have a negative impact on their bilateral relations. As a result of this unprecedented event, Ethiopia can be considered a manifestation of the policy change.

In line with Eritrea, Ethiopia wants to make the region a major trading hub. This would create a favorable environment for the use of the two Eritrean ports. Thus, the market and investment option in Eritrea provides a favorable opportunity for Ethiopia (Abraha, 2019).

This could be attributed to the Ethio-Eritrean reconciliation. It is clear that both countries will find it difficult to implement these options in accordance with previous policy approaches. So, their only option is to change their outlook on foreign policy.

\section{Political Reform: The Importance of Liberalized Economy and Regional Integration}

Another reason of the policy change is the result of existing politics. Ethiopia has recently been undergoing a major political reform. These changes suggest that there is an increasing need for new forms of foreign relations in Ethiopia.

Previously, the government that once opposed the Liberal economic model now says that the liberal way will update the economy and accelerate growth. In the past, the Horn of Africa would have said that although it is economically viable to form regional economic integration, the security situation in the region is a hindrance. However, now the government acknowledges that it is difficult to achieve the desired growth without a real-time economic integration. These two major issues are the new political changes the government is promoting. Let us 
have a detailed look at how changes can relate to policy change.

Ethiopia's desire is now accompanied by effort to grow its economy. In the previous government, there was strong opposition to the Liberal Development Model. As a result, huge economic networks were controlled by the government. The Ethiopian government had to choose alternative developmental modules because the idea of liberalism came to be called the "Night watchman" (Teshome, 2012). As a result, it had designed its own program and continues to keep large institutions under government control. The government called this a "developmental state" in relation to economic growth in Southeast Asia.

But as soon as the new prime minister took power, Ethiopia urges the economy should be liberalized so that the economy can grow fast. The government promised to work on inviting private investors to the mega institutions. However, for some, privatization existed in Ethiopia since EPRDF took power, and doubt whether the neo liberation save Ethiopia's economy (Lakew, 2018).

The accompanying bill begins with the repeal of a proclamation declaring state institutions to be the sole government. This is the work of the legislature. The point is, however, that sees the source of the impact. Prior to the transition of power, the United States had promised that the United States would keep its promise to diversify and liberalize Ethiopia's economy (A week in the Horn, 2018).

According to the Ethiopian Foreign Relations Policy, Ethiopia outlines the alternatives to be used by countries. In this regard, as it poses a threat to the Horn of Africa, it refers to the West's economic support. In this respect, it describes that the US can support Ethiopia's financial sector in particular, given its large share in the global market. However, in the context of policy interaction, would focus on using Ethiopian community in the United States. It defines how these patriots would play a role in helping America to support Ethiopia.

It describes the expedition to Asia in contrast. It appreciates the fact that countries in Asia have witnessed significant economic growth in the short term. It further outlines China's limited capabilities, expresses its commitment to Ethiopia's development, and clarifies that it will encourage Ethiopia to make its choices in terms of China's foreign investment.

Recently, the ideology that Ethiopia intends to follow is known as the economic Liberalization. However, previously, this was said to be democratic and developmental program. Many countries were engaged in the private sector from Asia following this program in Ethiopia. China, India and Pakistan could be mentioned among them. Now that this economic pathway is changing, the question of whether these processes will invite these countries are still invoke another study. Instead, Ethiopia, in this case, in addition to financial support, shows an interest in attracting Western attention through development. The fact that Ethiopia has been protecting some state economic sector from the eyes of the Liberals may become history in future. As a result, Western involvement in Ethiopia's infrastructure and economic sector may become a reality.

Prime Minister Abiy held a wide-ranging discussion on Ethiopian affairs and 
foreign diplomacy with the Ethiopian ambassadors abroad on January 14, 2019. In this discussion, among other issues, the need to improve foreign policy and the importance of economic integration in East Africa not only need attention but also urges. As a country without a seaport, it is evident from their belief that Ethiopia cannot maintain a better economy. Accordingly, it is possible to understand the direction of Ethiopia's foreign policy.

In case, National interest can be replaced by strategic interest, the former economist view of the developmental government, will be replaced by a liberal. The countries that are accused of terrorism in the Horn of Africa will be exempt from the accusations made against them based on economic interests.

The policy of 2002 is a cautionary tale with regard to the horn of Africa. The document states that the socio-economic link of the region will contribute significantly to Ethiopia national interest. On the other hand, it is a zone where a rapidly changing political process is dangerous. Therefore, it is advisable to take extreme care not to jeopardize the national interest of Ethiopia (Negera, 2018).

The importance of economic integration in East Africa may be of great importance. The prime minster is now taking the initiative in political reform and embarking regional integration initiatives (Costantinos, 2018). However, the region is characterized by high conflict, high external pressure, and the political system of the country. In this way it is difficult to bring economic diversity easily.

For example, the Ethiopian Constitution states that the federal government's main role was to unite regional economies and create a common economic community. However, it has not been possible for the past two decades. Therefore, the same line of communication should clearly state what should be done to prevent the same process from occurring in foreign policy.

\section{The Issue That Needs to be Improved Together during Change}

Beyond the above justification, there is another flaw of the policy. This gap may have helped improve policy but not change. However, while the policy direction indicate the need for change, these might need to be improved as well. The new policy, therefore, is estimated to be exploratory as well regarding the following issues. The 2002 policy has shown some structural outline problem. The policy is composed of two parts. The first part was an introduction to which policy issues are discussed extensively. In this part, national honor is taken seriously as pillars of the policy. The other concerns globalization and explores the potential economic linkages that follow.

The second part is an exploration of relations with countries. This section is divided into seven chapters. These were the details of the relationship between the Horn of Africa, other African countries, the Middle East, Europe, North America, Asia, and international and nongovernmental organizations.

The first chapter deals with the Horn of Africa. No significant geographical 
fault is given in this chapter. All countries included in this chapter are located on the Horn of Africa. These are Eritrea, Somalia, Sudan, Djibouti and Kenya. In addition, the issue of strengthening the IGAD has been detailed (Ministry of Information, 2002: pp. 60-110). However, this shows that there is a gap in the culture of law reform in Ethiopia following current issues. The reason for this is that the policy framework was developed before the declaration of South Sudan independent. yet, there has been no reform.

The second chapter, without mentioning geographical location, deals with relationships with other African countries (Ministry of Information, 2002: pp. 110115). The third chapter deals with relations with the Middle East. However, the first country is Egypt. This chapter covers in addition to Egypt, the Arabian Peninsula, Israel, Turkey and Iran, and North Africa (Ministry of Information, 2002: pp. 115-140). This policy does not explain why Egypt and North Africa merged countries with the Middle East, and indeed, as the chapter explores, Ethiopia is closer to the Middle East than Africa because of its proximity to the Middle East. But proximity and geographical location are different. Egypt and North African countries are completely geographically located in Africa. In fact, they are closer to the Middle East than Ethiopia. This shows that strategic interest has influenced the policy directive.

The fourth category is Europe, which includes the European Union and the Russian Federation (Ministry of Information, 2002: pp. 141-147). Much attention has been paid to the Russian Federation. The Fifth Chapter is about America (Ministry of Information, 2002: pp. 148-151). This section focuses on the United States. But does not explore other North American countries. The sixth chapter deals with Asia, first of all, providing a general overview of its relationship with Asia. It then outlines the relationship between Japan, China and India (Ministry of Information, 2002: pp. 151-157). The final chapter lists the ways in which Ethiopia works with international organizations and NGOs (Ministry of Information, 2002: p. 157).

There is no clear explanation of how the issue of geographical positioning has been dealt with in this chapter. Apart from that, countries that have longer connections to Ethiopia in North America are also excluded. In the chapter on America, it is not even summarized as a comprehensive analysis of North America like that of Asia. In addition to this, the policy does not state anything regarding South America. However, significant relation has been under goes with countries in South America.

\section{Conclusion}

Readi Abrha argues that the 2002 foreign policy focuses on strategy rather than policy (Abraha, 2019). In fact, strategy is designed to reach a goal or reduce a risk. It is not difficult to truly understand that the document had strategic framework in line with policy. From the beginning, the policy was initially given the title "Ethiopia's Foreign Affairs and National Security". From this, it appears 
that the policy also aims to protect the national threat that may arise from foreign relations led by the government.

Foreign policy is used by a nation to maintain its statuesque and to eliminate what is not (Palmer \& Morgan, 2006). This requirement can be embraced by policy and, in contrast, the strategy can be used to facilitate the minimalization of vulnerability as well as the avoidance of danger.

Looking at the above, Redai states that the policy is formulated by politicians, rather than the experts. In fact, Meles "authored" it (de Wall, 2015). For that matter, it would be convenient to say that the policy was fully influenced by political actors, since the policy was officially announced after the end of the war between Ethiopia and Eritrea.

However, there are so many reasons that the previous policy cannot continue. Ethiopian is in fast political dynamics and the foreign relations has also transformed. If the policy does not change during this process, it can be considered a hindrance to many incidents.

The question of how these changes come about, however, is important in considering the political role of the actors. As we have seen in detail, the two leaders, who appeared at different times in Ethiopia, personally influenced the political transitions. With a diplomatic effort, the new administration's is working to resolve any gap in the policy process. However, there is a fact to be cautioned. The history of the relationship between Ethiopia and East Africa can be traced. Ethiopia has a history of friendship and hostility with these countries. As a result, it is dangerous to bring the desired change overnight. Care must be taken not to exploit Ethiopia's friendly and peaceful way of dealing with these countries. A great attention must be taken to ensure that the social and economic linkage of the region makes it ideal for conflict as East Africa's regional interaction itself invites conflict. Otherwise, when it comes to economic ties, it needs to check that something is done to safeguard the country's survival and security. In fact, democracy, development and rapid economic growth are crucial. In short, the key role of national security must be kept in mind that the road to this goal will not lead to a complicated situation.

In general, foreign affairs policy has been widely discussed in ways that make the policy Change. The reconciliation between Ethiopia and Eretria at the time, privatization and liberalizing economy and changing the country's political environment are the most in which the political actors play a significant role.

\section{Conflicts of Interest}

The authors declare no conflicts of interest regarding the publication of this paper.

\section{References}

Abraha, R. (2019). Ethiopian Foreign Policy towards African State and the Nile Basin Countries: A Comparative of the 2002 and 2019 Policy. 
Alden, C., \& Ara, A. (2017). Foreign Policy Analysis New Approaches. New York: Routledge. https://doi.org/10.4324/9781315442488

Costantinos, C. B. (2018). Priming Peace, Integration \& Livelihood Security in the Horn of Africa: The Greater Horn of Africa "Manifesto".

de Jong, J. (2012). Rethinking Rational Choice Theory: A Companion on Rational and Moral Action. New York: Palgrave Macmillan. https://doi.org/10.1057/9780230355545

de Mesquita, B. B. (2010). Foreign Policy Analysis and Rational Choice Models. New York: New York University/Stanford University.

De Wall, A. (2012). The Theory and Practice of Meles Zenawi. African Affairs, 112, 148155. https://doi.org/10.1093/afraf/ads081

De Wall, A. (2015). The Real Politics of the Horn of Africa: Money, War and the Business of Power (p. 149). Cambridge: Polity Press.

Harsanyi, J. C. (1986). Advances in Understanding Rational Behavior. In J. Elster (Ed.), Rational Choice (pp. 82-107). Oxford: Basil Blackwell.

Healy, S. (2008). Eritrea's Regional Role and Foreign Policy: Past, Present and Future Perspectives. London: Chatham House, Africa Program.

Holsti, K. (2016). Restructuring Foreign Policy: A Neglected Phenomenon in Foreign Policy Theory. In K. Holsti (Ed.), Kalevi Holsti: A Pioneer in International Relations Theory, Foreign Policy Analysis, History of International Order and Security Studies (pp. 103-119). Berlin: Springer. https://doi.org/10.1007/978-3-319-26624-4 9

Kassab, H. S. (2017). Prioritization Theory and Defensive Foreign Policy: Systematic Vulnerabilities in International Politics. London: Palgrave Macmillan.

https://doi.org/10.1007/978-3-319-48018-3

Lakew, W. G. (2018). Can Neo-Liberalism Save Ethiopia. https://borkena.com

Lichbach, M. L. (2003). Is Rational Choice Theory of All Social Sciences? Ann Arbor, MI: The University of Michigan Press. https://doi.org/10.3998/mpub.11998

Lkenberry, G. J. (1986). The Sate and Strategies of International Adjustment. World Politics, 39, 54. https://doi.org/10.2307/2010298

Mingst, K. A., \& Arreguintoft, I. M. (2011). Essentials of International Relation. New York: W. W. Norton \& Company, Inc.

Ministry of Foreign Affair (2018). A Week in the Horn. https://mfaethiopiablog.wordpress.com

Ministry of Information (2002). The Federal Democratic Republic of Ethiopia Foreign Affairs and National Security Policy and Strategy. Addis Ababa.

MLA Style (2020). The Nobel Peace Prize for 2019. https://www.nobelprize.org/prizes/peace/2019/press-release

Müller, F. (2015). Model Transfer in the Making: Changing Development Strategies of and Expectations towards, the State in Ethiopia and Ghana. Working Paper Series Nr. 15.

Negera, G. (2018). The Determinants of Ethiopian Foreign Policy under Consecutive Regimes: Appraisal of Military and EPRDF Government Determinants of Ethiopian Foreign Policy. International Journal of Political Science and Development, 6, 192-199.

Palmer, G., \& Morgan, T. C. (2006). A Theory of Foreign Policy (p. 26). Princeton, NJ and Oxford: Princeton University Press.

Rosati, J. A. (1994). Cycles in Foreign Policy Restructuring: The Politics of Continuity and Change in U.S. Foreign Policy. In J. A. Rosati, J. D. Hagan, \& M. W. Sampson (Eds.), Foreign Policy Restructuring. How Governments Respond to Global Change 
(pp. 221-261). Columbia, SC: University of South Carolina Press.

Sato, Y. (2013). Rational Choice Theory.

Skidmore, D. (1994). Explaining State Responses to International Change: The Structural Sources of Foreign Policy Rigidity and Change. In J. A. Rosati, J. D. Hagan, \& M. W. Sampson (Eds.), Foreign Policy Restructuring. How Governments Respond to Global Change (pp. 43-61). Columbia, SC: University of South Carolina Press.

Teshome, A. T. (2012). Meles's Development Paradigm and Its Impacts on Economic Transformation in Ethiopia. Global Advanced Research Journal of Management and Business Studies, 1, 384-396.

The Offical Blog of MFA Ethiopia (2019). Prime Minster Dr. Abiy Briefs Ethiopia's Ambassadors on Foreign Polciy.

https://mfaethiopiablog.wordpress.com/2019/01/18/prime-minter-dr-abiy-breifs-ethio pias-ambassadors-on-foreign-policy/ 